American Journal of Pharmacology and Toxicology 4 (4): 144-150, 2009

ISSN 1557-4962

(C) 2009 Science Publications

\title{
Assessment of the Mutagenicity of Some Pharmaceutical Effluents
}

\author{
${ }^{1}$ A. Akintonwa, ${ }^{1}$ O. Awodele, ${ }^{1}$ A.T. Olofinnade, ${ }^{2}$ C. Anyakora, \\ ${ }^{1}$ G.O. Afolayan and ${ }^{2}$ H.A.B. Coker \\ ${ }^{1}$ Department of Pharmacology, College of Medicine, University of Lagos, Nigeria \\ ${ }^{2}$ Department of Pharmaceutical Chemistry, Faculty of Pharmacy, \\ University of Lagos, Nigeria
}

\begin{abstract}
Problem statement: The pharmaceutical industry is a major contributor to industrial wastes globally. Effluents from this industry are usually discharged into the environment and when not properly handled and disposed, they affect both human health and the environment. Approach: This study evaluated the mutagenic potentials of effluents from six pharmaceutical companies in the Lagos province of Nigeria using modified Ames test and Allium cepa (Linn) assay. Allium cepa model was used to determine the mean root length, mitotic index and chromosomal aberrations effects of these plants on Onion bulbs using 5, 10 and $15 \%$ concentration of the pharmaceutical effluents. The modified Ames test which is a modification of the standard Ames test was done using E. coli (0157:H7) that has the phenotypic characteristics of glucose and lactose fermentation, motile, urease negative, indole positive and citrate negative. Result: From the results, two of the effluents showed mutagenicity with modified Ames test and all the six effluents showed mitodepressive and toxic effects to the Allium cepa root. Conclusion/Recommendations: It may then be recommended that pharmaceutical companies should devise means of containing, treating and managing their effluents.
\end{abstract}

Key words: Pharmaceutical effluent, Ames test, Allium cepa assay, mutagenicity

\section{INTRDUCTION}

The growing use of Pharmaceutical products is becoming a new environmental challenge. For several years now the use of Pharmaceutical products has been on a steady rise, mainly due to a rise in the aging population in most nations. In the United States, for example, the pharmaceutical industry has been growing twice as fast as the rest of the US economy ${ }^{[14]}$. The same happens in much other country to varying degrees. This rise in the use of pharmaceutical products results also in the proportional rise in the possibility of these compounds being present in the environmental samples. The study of Velagaleti et al. ${ }^{[18]}$ has documented the potentials for Pharmaceutical chemicals to have long term effects on the environmental species. During the last few years, the interest to assess the presence of Pharmaceutical compounds in the environment has been on the increase ${ }^{[6]}$. However, there were reports concerning the occurrence of Pharmaceutical residue in the environment even during the 1970 's ${ }^{[10]}$. Preliminary results from studies conducted in North America and some European countries have confirmed the presence of many pharmaceuticals ${ }^{[3,4,12,21,23]}$.
Pharmaceutical effluents are waste generated by pharmaceutical industry during the process of drugs manufacturing and the steps involve in compounding of drugs (which include extraction, processing, purification and packaging) generate air emission liquid waste and solid waste. The occurrence of numerous pharmaceuticals in municipal waste water and in surface waters that receive waste water effluent have been reported by ${ }^{[3,4,11,12]}$. Liquid effluents resulting from equipment cleaning after batch operation contain toxic organic residues. Their composition varies depending on the product manufactured, the materials used in the process and other process details ${ }^{[17]}$. Thus, the Biochemical Oxygen Demand (BOD) Chemical Oxygen Demand (COD) suspended solids as well as phenol and $\mathrm{pH}$ of pharmaceutical effluent are not consistent depending on the product manufactured, material used and the processing details ${ }^{[16]}$.

The risk of pharmaceutical effluents to human health and environmental species cannot be overemphasized, hence there is a great need for this to be established. The US Food drug and administration

Corresponding Author: Olufunsho Awodele, Department of Pharmacology, College of Medicine, University of Lagos, Nigeria Tel: +2348023624044 
has recommended that toxicity test $\left(\mathrm{LC}_{50}, \mathrm{EC}_{50}\right)$ using both aquatic and terrestrial organism, Algae species bioassay test and other necessary test should always be carried out on pharmaceutical effluents ${ }^{[20]}$. The increasing use of various pharmaceutical in Nigeria has resulted in an astronomical rise of pharmaceutical manufacturing companies in Lagos. Many of these companies are small scale and tend to exhibit some carelessness in the way they handle their waste. These are known to be among the major contributors to industrial wastes. Their effluents are usually discharged into the environment and when improperly handled and disposed, they affect both human health and the environment ${ }^{[16]}$. This study is an attempt to screen some effluents randomly selected for their mutagenic potentials. This was achieved using modified Ames test and Allium cepa linn assay

\section{MATERIALS AND METHODS}

Two methods were used for the assessment of mutagenicity of the effluents. They include: Modified Ames Test and Allium cepa (Linn) Assay. Details of these tests are described below.

Modified ames test: This is a modification of the standard Ames assay as described by Ames et al. ${ }^{[2]}$.

Pharmaceutical effluent collection: Pharmaceutical effluents were collected from six indigenous pharmaceutical companies in Nigeria upon the issuance of ethical clearance to carry out the study. The six Pharmaceutical companies are denoted as PE1, PE2, PE3, PE4, PE5 and PE6.

Media preparation: The various media that were used for this assay are MacConkey agar, Kliger iron agar, Motility indole urea, Simmon citrate, Brain heart infusion agar, Nutrient agar and Brain heart infusion broth. The preparation of these media was in accordance with the procedure of the LAB $M^{\mathrm{TM}}$ (Topley Home, 52 Washlane Bury, Lancanshire, BL96AU, UK).

Preparation of the Rat microsomal liver enzyme (S9): Two Sprague-Dawley rats weighing about $180 \mathrm{~g}$ each were obtained from the animal house of the College of medicine of the University of Lagos. The rats were injected intra-peritoneally with $10 \mathrm{mg} \mathrm{kg}^{-1}$ of Phenobarbitone for three days to induce the liver microsomal enzymes as suggested by Maron and Ames ${ }^{[15]}$. After the third day, the animals were sacrificed and the liver was extracted aseptically and then macerated using a prior sterilized mortar and pestle. To every $1 \mathrm{~g}$ of the macerated liver, $5 \mathrm{~mL}$ of 1.65 $\mathrm{M} \mathrm{KCl}$ solution was added. The resulting solution was centrifuged (1200 revolutions $\mathrm{min}^{-1}$ ) and the supernatant was filtered using a sterile membrane filter to obtain the rat microsomal enzyme.

The S9 mix: The S9 mix was freshly prepared using the method of Maron and Ames ${ }^{[15]}$. Thus, $20 \mathrm{~mL}$ of S9 mix contains $2 \mathrm{mls}$ of rat liver enzyme, $10 \mathrm{~mL}$ of $0.2 \mathrm{M}$ phosphate buffer at $\mathrm{pH}$ of 7.4, 5.6 mL of distilled water, $1 \mathrm{~mL}$ of $80 \mathrm{mM}$ NADP sodium salt hydrate, $1 \mathrm{~mL}$ of $120 \mathrm{mM}$ Glucose-6-phosphate and $0.4 \mathrm{~mL}$ of potassium and magnesium salts solution. The mixture was stirred properly before $2 \mathrm{~mL}$ of the rat liver enzyme (S9) was added.

Inoculation: The MacConkey agar plates were subcultured with strain of E. coli $(0157: \mathrm{H} 7)$ obtained from the Genetics department of the Nigerian Institute of Medical Research, Yaba-Lagos (NIMR) and incubated at $37^{\circ} \mathrm{C}$ for $24 \mathrm{~h}$ to obtain discrete colonies. Thus, the discrete colonies of the organism were re-sub cultured into new MacConkey plates and incubated at $37^{\circ} \mathrm{C}$ for $24 \mathrm{~h}$ to ensure the use of standard strain of the organism and not contaminants. This organism has biochemical characteristics of lactose and glucose fermenting, motile, urease negative, indole positive and citrate negative.

Bacteria mutation assay: The assay was performed using E. coli (0157: H7) which have been grown on MacConkey plates to obtain discrete colonies. The experiment was performed in the presence and absence of metabolic activation of the rat liver enzyme. The fraction of the liver enzyme (S9) was used at a concentration of $10 \%(\mathrm{v} / \mathrm{v})$ in the S9 mix. The S9 mix was freshly prepared for the experiment according to the method of Maron and Ames ${ }^{[15]}$. Test agents and positive control were tested with this strain of organism for this experiment, Ethidium bromide which is a known intercalating agent was used as the positive control. Fresh culture of tested strain obtained from MacConkey plate was inoculated and grown in the brain heart infusion broth. The brain heart infusion broth containing the organism was incubated for $10-12 \mathrm{~h}$ at $37^{\circ} \mathrm{C}$ in order to ensure adequate aeration. $0.1 \mathrm{~mL}$ of the brain heart infusion broth that contains the organism was mixed with $0.5 \mathrm{~mL} \mathrm{~S} 9 \mathrm{mix}$ and $0.1 \mathrm{~mL}$ of the test sample. The mixture was incubated at $37^{\circ} \mathrm{C}$ for $24 \mathrm{~h}$ and later seeded into the brain heart infusion agar plates, while the other portion without $\mathrm{S} 9$ was also seeded on other brain heart infusion agar plates. The plates were incubated at $37^{\circ} \mathrm{C}$ 
for $72 \mathrm{~h}$. The revertant strains produced were inoculated into the KIA, MIU and Citrate agar to re-examine the organism's biochemical characteristics. An alteration in at least 3 biochemical characteristics out of the 7 biochemical characteristics will be taken as the bench mark for mutagenicity. However, alteration in biochemical characteristics lesser than 3 may illustrates a weak mutagenicity or no mutagenicity.

Allium cepa linn assay: The Allium test provides a rapid screening procedure for chemicals and environmental agents which may represent environmental hazards. Root growth inhibition and adverse effects on chromosomes provide an indication of likely toxicity.

Healthy equal sizes of common onions were obtained from Bariga local market of Lagos, Nigeria. The dried outer scales were carefully removed leaving the ring of the root primodial intact ${ }^{[9]}$. Five onion bulbs were utilized for each concentration of: 5, 10 and 15\% of Pharmaceutical effluents.

Tap water of good quality was used for negative control. The base of each of the onion bulbs was grown on each of the concentration of the environmental agents inside a $30 \mathrm{ml}$ beaker and placed away from sunlight for 4days after which the root length was measured.

Root growth inhibition test: The toxicity assay was performed as a $96 \mathrm{~h}$ semi-static exposure test and three (3) concentrations of the test samples were used. Every $24 \mathrm{~h}$ the test solutions were replaced by fresh solutions. The test solutions were used at room temperature and at the termination of the exposure, the length of the root bundles were measured and their mean \pm SE were calculated

Microscopic analysis: The root tips at a length of $10 \mathrm{~mm}$ were cut off and fixed in Acid: Alcohol solution $(1: 3)$ by heating for $5 \mathrm{~min}$ at $50^{\circ} \mathrm{C}$. Thereafter the terminal root tips (1-2 mm) were cut off and squashed on the slide and stained with Orcein solution for $10 \mathrm{~min}$. The cover slip was then carefully lowered on the stained area to avoid air bubble and slides were carefully dampened with the use of a filter paper to remove the excess stain. The cover slip was fixed carefully to the slide with nail varnish.

The slides were examined under the microscope to determine the mitotic index and chromosomal aberrations. The Mitotic Index (MI) was determined by counting all stages of mitotic cells out of 1000 cells:

$$
\text { Mitotic index }=\frac{\text { No. of dividing cells }}{\text { Total number of cells analyzed }} \times 1000
$$

The slides were examined from right to left; up and down and the first 100 metaphase, Anaphase and Teleophase cells were scored for aberrations.

\section{RESULTS}

Table 1 shows the results of Pharmaceutical effluents to modified Ames test. The results revealed the normal biochemical characteristics of $E$. coli (0157:H7) to be Citrate and Urease negative, Indole positive, Glucose and Lactose fermenting, Motile and produced Carbon dioxide gas. Ethidium bromide which is the positive control showed an alteration in some of these normal biochemical characteristics of the organism.

Table 1: Normal biochemical characteristics of E. coli $(0157: \mathrm{H} 7)$ and the biochemical characteristics of $E$. coli $(0157: \mathrm{H} 7)$ after treatment with some Pharmaceutical effluents and Ethidium bromide

\begin{tabular}{|c|c|c|c|c|c|c|c|c|}
\hline \multirow[b]{2}{*}{ Strain/Pharmaceutical effluents } & \multicolumn{4}{|c|}{ Kliger Iron Agar (KIA) } & \multicolumn{3}{|c|}{ Motility Indole Urea (MIU) } & \multirow[b]{2}{*}{ Simmons citrat } \\
\hline & Butt & Slant & $\mathrm{H}_{2} \mathrm{~S}$ & Gas & Motility & Indole & Urease & \\
\hline \multicolumn{9}{|c|}{ Characteristics of Escherichia coli $(E$. coli) $(0157: \mathrm{H} 7)$} \\
\hline 0517:H7 & GF & LF & - & + & + & + & - & - \\
\hline \multicolumn{9}{|c|}{ Characteristics of revertant strains of $E$. coli $(0517: \mathrm{H})$ after treatment with some pharmaceutical effluents and ethidium bromide } \\
\hline PE1 & GF & $\mathrm{NLF}^{\mathrm{g}}$ & - & $-e^{e}$ & $-d^{d}$ & $-\mathrm{c}$ & $++^{\mathrm{b}}$ & - \\
\hline PE2 & GF & LF & - & + & + & $-\mathrm{c}$ & $++^{\mathrm{b}}$ & - \\
\hline PE3 & GF & LF & - & + & + & + & - & - \\
\hline PE4 & GF & $\mathrm{NLF}^{\mathrm{g}}$ & - & $-{ }^{\mathrm{e}}$ & $-{ }^{d}$ & $-{ }^{c}$ & $t^{\mathrm{b}}$ & - \\
\hline PE5 & GF & $\mathrm{LF}$ & - & + & + & + & - & - \\
\hline PE6 & GF & $\mathrm{LF}$ & - & + & + & + & - & - \\
\hline Ethidium bromide & GF & $\mathrm{NLF}^{\mathrm{g}}$ & $t^{f}$ & + & $-{ }^{\mathrm{d}}$ & + & $t^{\mathrm{b}}$ & $t^{\mathrm{a}}$ \\
\hline
\end{tabular}

Key: GF: Glucose Fermenting; LF: Lactose Fermenting; NLF: Non Lactose Fermenting, +: Positive; -: Negative; ${ }^{\text {a }}$ Citrate positive; ${ }^{\text {b}: ~ U r e a s e ~}$ positive; ${ }^{\text {c }}$ Indole negative; ${ }^{\text {d }}$ : Not motile; ${ }^{\text {e }}$. Not produce gas; ${ }^{\mathrm{f}}:$ Produced hydrogen sulphide; ${ }^{\mathrm{g}}$ : Non lactose fermenting 
Am. J. Pharm. \& Toxicol., 4 (4): 144-150, 2009
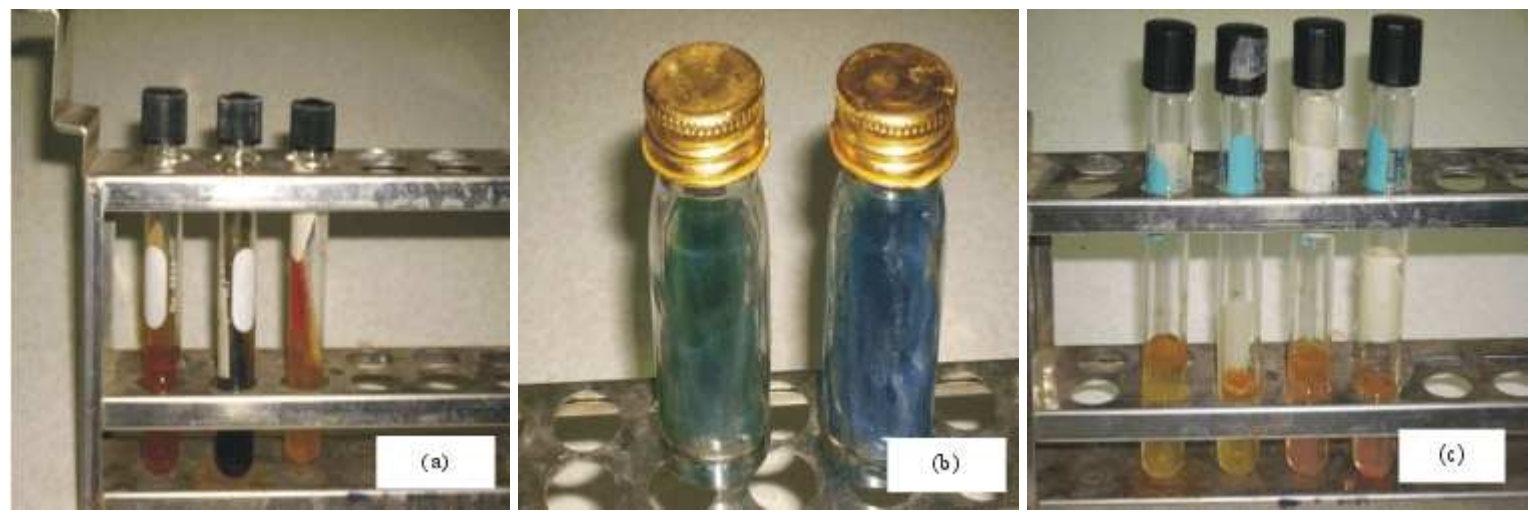

Fig. 1: Appearance of KIA, MIU and Simmon citrate after inoculating with revertant strains of E. coli 0157:H7. Key: (a) Kliger Iron Agar media (KIA), (b) simmon citrate media, (c) Motility Indole Urea (MIU) media

Table 2: Effects of various concentrations of pharmaceutical effluents on the cytology and root growth of Allium cepa Pharmaceutical effluents

\begin{tabular}{|c|c|c|c|c|c|c|c|c|}
\hline \multirow[b]{2}{*}{ Treatment conc. (\%) } & \multicolumn{4}{|c|}{ Phenotypic indices } & \multicolumn{4}{|c|}{ Chromosome aberrations } \\
\hline & $\begin{array}{l}\text { No. of } \\
\text { dividing cells }\end{array}$ & MI & length $\pm \mathrm{SE}$ & $\begin{array}{l}\text { Mean root } \\
\text { Stickiness }\end{array}$ & anaphase & $\begin{array}{l}\text { Multipolar } \\
\text { fragments }\end{array}$ & $\begin{array}{l}\text { Bridges and } \\
\text { C-mitosis }\end{array}$ & Vagrant \\
\hline \multicolumn{9}{|l|}{ PE1 } \\
\hline Control & 52 & 126 & $4.45 \pm 0.35$ & 0 & 0 & 0 & 0 & 0 \\
\hline 5 & 28 & 68 & $3.20 \pm 0.28^{\mathrm{a}}$ & 7 & 0 & 3 & 1 & 5 \\
\hline 10 & 27 & 57 & $3.20 \pm 0.35^{\mathrm{a}}$ & 5 & 0 & 3 & 0 & 10 \\
\hline 15 & 26 & 55 & $3.10 \pm 1.13^{\mathrm{a}}$ & 7 & 0 & 2 & 0 & 8 \\
\hline \multicolumn{9}{|l|}{ PE2 } \\
\hline Control & 52 & 126 & $4.45 \pm 0.35$ & 0 & 0 & 0 & 0 & 0 \\
\hline 5 & 53 & 114 & $4.10 \pm 0.14^{\mathrm{a}}$ & 6 & 0 & 5 & 4 & 5 \\
\hline 10 & 53 & 114 & $4.10 \pm 0.14^{\mathrm{a}}$ & 7 & 1 & 6 & 0 & 6 \\
\hline 15 & 51 & 104 & $4.10 \pm 0.14^{\mathrm{a}}$ & 6 & 1 & 5 & 5 & 6 \\
\hline \multicolumn{9}{|l|}{ PE3 } \\
\hline Control & 52 & 126 & $4.45 \pm 0.35$ & 0 & 0 & 0 & 0 & 0 \\
\hline 5 & 29 & 91 & $0.20 \pm 0.14^{\mathrm{a}}$ & 2 & 0 & 2 & 1 & 8 \\
\hline 10 & 24 & 53 & $0.20 \pm 0.14^{\mathrm{a}}$ & 0 & 0 & 4 & 1 & 4 \\
\hline 15 & 23 & 52 & $0.20 \pm 0.14^{\mathrm{a}}$ & 7 & 0 & 4 & 0 & 3 \\
\hline
\end{tabular}

KEY: a: $\mathrm{p}<0.05$ (compare with control)

It produced mutant strains that showed positive results to Citrate and Urease, not able to ferment lactose, not motile and produced hydrogen sulphide gas. The Table 1 further showed PE1, PE2 and PE4 effluents to produce mutant strains that gave positive results to Urease and negative results to Indole. Moreso, the results showed the PE1 and PE4 effluents not to produce mutant strains that produced carbondioxide gas, not lactose fermenting and not produce motile organism. The results of 3, 5 and PE 6 effluents showed no alteration of the normal biochemical characteristics of the organism. Figure 1 shows revertant strain producing hydrogen sulphide in KIA, there was also revertant strain that altered the butt and did not change the normal orange color of the slant indicating loss of ability to ferment fructose. There was color alteration from green to blue in Simmon citrate media after inoculating with revertant strain indicating a positive result to citrate utilization. The MIU also showed absence of red ring above the media upon the addition of kovarsc reagent after inoculating with revertant strain indicating negative result to indole production. There was also color alteration of MIU from yellow to pink after the inoculation of revertant strain showing the utilization of urease.

The results in Table 2 showed the Cytotoxic and Root growth inhibitory effects of various concentrations of Pharmaceutical effluents obtained from different companies on Allium cepa. The results obtained from PE1 revealed a concentration dependent decrease in root length, as the concentration increases from 5-15\% the root length significantly decreased $(\mathrm{p}<0.05)$ compare with the control. The results of PE2 and PE3 effluents showed a constant mean root length growth of Allium cepa from 5-15\% concentrations but significantly decreased $(\mathrm{p}<0.05)$ when compared with the control. 
Am. J. Pharm. \& Toxicol., 4 (4): 144-150, 2009

Table 3: Effects of various concentrations of pharmaceutical effluents on the cytology and root growth of Allium cepa

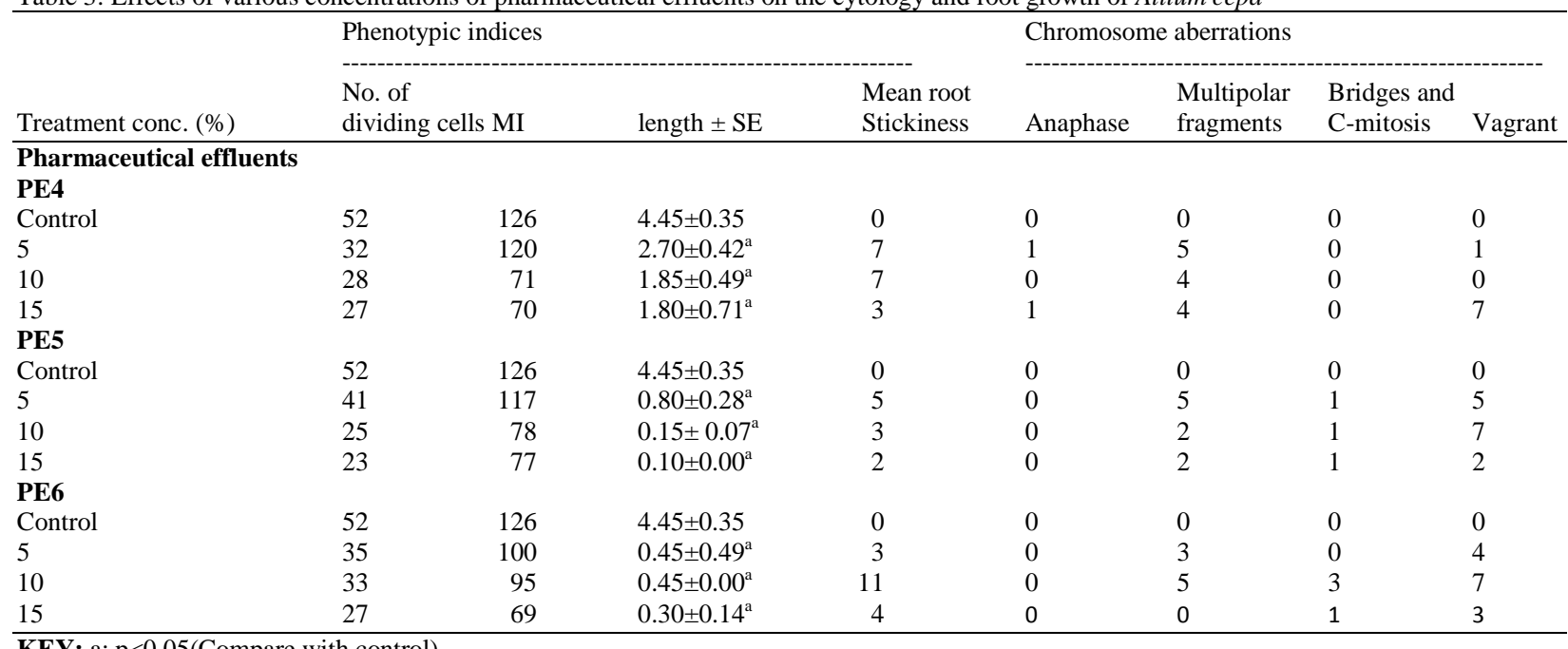

KEY: a: p<0.05(Compare with control)

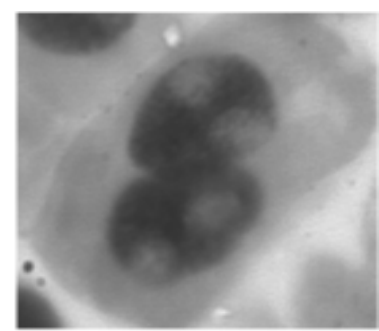

(a)

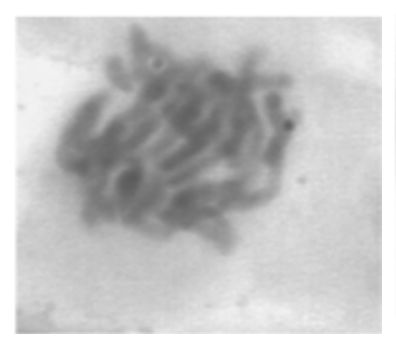

(c)

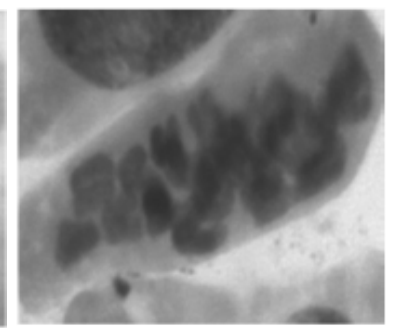

(b)

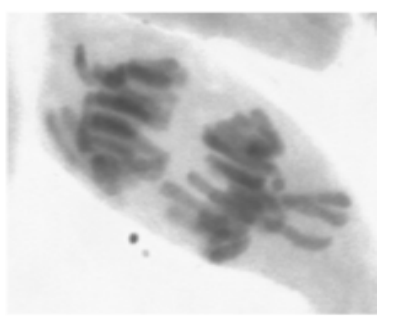

(d)
Fig. 2: Aberrations at various stages of mitotic division in cells of Allium cepa treated with the mixture of different pharmaceutical effluents. Mag. × 1000. Stain: Orcein; (a) BINulei; (b) C-mitosis; (c) Anaphase with laggards; (d) bridges and fragments

The results further revealed a concentration dependent decrease in mitotic index from $5-15 \%$. The results of the three effluents showed the occurrences of Stickiness, Bridges and fragments, multipolar anaphase, C-mitosis and vagrant chromosomal aberrations.

The results on Table 3 showed the Cytotoxic and Root growth inhibitory effects of various concentrations of Pharmaceutical effluents obtained from different companies on Allium cepa. The results obtained from PE6, PE5 and PE4 effluents revealed a concentration dependent decrease in mitotic index and mean root length from $5-15 \%$ which is significant $(p<0.05)$ compared with control. All the three effluents showed the occurrences of Stickiness, Multipolar Anaphase, Bridges and fragments, C-mitosis and Vagrant Chromosomal aberrations. As can be seen in Fig. 2, various aberrations were observed in the root cells of the Allium cepa. Most of the aberrations were observed at the Anaphase stage of mitotic division. Some of the chromosomes were linked together instead of Separating to the poles forming bridges and fragments. There was also a lag observed in the chromosomal migration to the poles.

\section{DISCUSSION}

Escherichia coli 0157:H7 was obtained from the Nigeria institute of medical research, Yaba-Lagos. The organism was subjected to the method of identification of Enterobacteriaceae as described by Edwards and Ewing $^{[8]}$ and Cowan ${ }^{[5]}$. The organism was found not to utilize citrate as its only source of carbon and a green colouration of the Simmon's citrate agar was obtained. However, a bright blue color of Simmon's citrate agar indicates positive results to citrate. The organism was also found not to produce Urease as it is unable to break down urea to ammonia and carbondioxide. Thus, a yellow color of Motility indole urea agar indicates negative results while Red/purple indicates positive results. Furthermore, the organism was observed to break down amino acid tryptophan with the release of indole. Thus, a red surface layer upon the addition of 
kovac's reagent indicates positive result to indole. While a yellow colouration of the Motility indole urea indicates negative results to indole. The organism was also observed to have a strand of movement in the motility indole urea agar, which showed the organism to be motile. Furthermore, an upward shift of the kliger iron agar from the bottom of the tube was observed which reflected carbon dioxide production. The organism demonstrated the ability to ferment both glucose and fructose with the alteration of the colour of the Kliger iron agar from orange to yellow.

The studies of Tixier-Boichard ${ }^{[19]}$, Kammenga ${ }^{[13]}$ and Deepa et $a l .{ }^{[7]}$ have all adduced the fact that phenotypic expression is always a function of genotype and the environment. Therefore, any alteration in the above mentioned normal biochemical characteristics of the organism may be due to alteration of the genetic material (DNA).Based on the above statement of fact, this study has therefore set a bench mark for mutagenicity to be any agent that altered at least (3) normal biochemical characteristics of the organism.

This study which may be the first of its kind has used both Modified Ames test and Allium cepa assay to assess the mutagenic potentials of Pharmaceutical effluents obtained from (6) Pharmaceutical companies denoted as 1, 2, 3, 4, 5 and PE6 Pharmaceutical effluents. The results of Modified Ames test showed that PE1 and PE4 Pharmaceutical effluents altered (5) biochemical characteristics of the normal E. coli out of the (7) biochemical characteristics investigated. They produced positive results to urease enzyme, negative results to indole production, non motile, non gas producing and non lactose fermenting. These results have demonstrated the mutagenic tendency of the effluents of 1 and PE4. However, the modified Ames test results with the effluents obtained from PE6, PE3 and PE5 showed no alteration of the normal biochemical characteristics of the organism. Moreso, the results obtained with the PE2 effluent showed an alteration of two (2) biochemical characteristics (urease positive and indole negative) of the normal organism. Thus, these results showed alterations of less than three biochemical characteristics and may not be classified to be mutagenic.

The results obtained from Allium cepa assay showed all the pharmaceutical effluents to have concentration dependent decrease in root growth length and mitotic index. Thus, as the concentration increases from $5-15 \%$ the mean root length decreases and the mitotic index also decreases. There were observation of chromosomal aberrations such as stickiness, multipolar anaphase, bridges and fragment, vagrant and c-mitosis observed. These results may be due to toxicity of the
Pharmaceutical effluents to the root of Allium cepa, the interference of the effluents with the process of mitotic division and interference of the effluents with the mitotic spindles. These results may be consistent with the earlier result of Akinboro and Bakare ${ }^{[1]}$ that reported the genotoxic effects of Medicinal plants using Allium cepa Linn assay.

\section{CONCLUSION}

The results obtained from this study have further unfolded the health risk of continual exposure to Pharmaceutical effluents. It may then be recommended that pharmaceutical companies should devise means of containing and managing their effluents.

\section{REFERENCES}

1. Akinboro, A. and A.A. Bakare, 2007. Cytotoxic and genotoxic effects of aqueous extract of five medicinal plants on Allium cepa Linn. J. Ethnopharmacol., 112: 470-475. http://cat.inist.fr/?aModele=afficheN\&cpsidt $=18913611$

2. Ames, B.N., J. Mccann and E. Yamasaki, 1975. Methods for detecting carcinogens and mutagens: A simple test system combining liver homogenates for activation and bacteria for detection. Proc. Natl. Acad. Sci. USA., 70: 2281-2285. http://www.pnas.org/content/70/8/2281.abstract

3. Buser, H.R., M.D. Muller and N. Theobald, 1998. Occurrence of the pharmaceutical drug clofibric acid and the herbiade mecoprop in various Swiss lakes and in the North Sea. Environ. Sci. Technol., 32: 188-192.

http://cat.inist.fr/?aModele=afficheN\&cpsidt=2136167

4. Buser, H.R., T. Poiger and M.D. Muller, 1998. Occurrence and fate of the pharmaceutical drug dichogenaic in surface waters: Rapid Photodegradation in a lake. Environ. Sci. Technol., 32: 3449-3456.

5. Cowan, S.T. 1973. Identification of Medical Bacteria. In: Manual for the Identification of Medical Bacteria, Cowan, S.T. and K.J. Steel (Eds.), 3rd Edn., Cambridge University Press, Cambridge, ISBN: 0521543282, pp: 238.

6. Daughton, C.G. and T.A. Ternes, 1999. Pharmaceutical and personal care products in the environment: Agents subtle change? Environ. Health Perspect. 107: 907-938. http://www.pubmedcentral.nih.gov/articlerender.fc gi? artid=1566206 
7. Sambandan, D., M.A. Carbone, R.H. Robert Auhoit and F.C. Trady Mackay, 2008. Phenotypic plasticity and genotype by environment interaction for olfactory behavior in Drosophilia melanogaster. Genetics, 179: 1079-1088. http://www.pubmedcentral.nih.gov/articlerender.fc gi? artid=2429861

8. Edwards, P.R. and W.H. Ewing, 1972. Identification of Enterobacteriaceae. 3rd Edn., Burgess Publishing Co. Minneapolis, Minn.

9. Fiskesjo, G., 1985. The Allium test as a standard in environmental monitoring. Hereditas, 102: 99-112. DOI: $10.1111 / \mathrm{j} .1601-5223.1985 . t b 00471 . x$

10. Garrison, A.W., J.D. Pope and F.R. Allen, 1996. In: Identification and Analysis of Organic Pollutants in Water, CH. Keith (Ed). Ann Arbor Sci. Pusl., Ann. Arbor, MI., pp: 517.

11. Hartmann, A., A.C. Alder and T. Koller R.M. Widmer, 1998. Identification of fluoquinolone antibiotics as the main source of UmmuC genitoxicity in native hospital waste water. Environ. Toxicol. Chem., 17: 371-382.

http://cat.inist.fr/?aModele=afficheN\&cpsidt=2232 565

12. Hirsch, R., T. Ternes, K, Habener and K.L, Kratz, 1999. Occurrence of antibiotics in the aquatic environment. Sci. Total Environ., 225: 109-118. http://www.ncbi.nlm.nih.gov/pubmed/10028708

13. Kammenga, J.E., 2007. Genetic Variation and Genome-Environment Interaction in $C$. elegans. Proceeding of the 14th Benelux Congress of Zoology, Amsterdam, The Netherlands, pp: 1-2.

14. Farre, M., I. Ferrer, A. Ginebreda, M. Figueras, L. Olivella, L. Tirapu, M. Vilanova and D. Barcelo, 2001. Determination of drugs in surface water and waste water samples by liquid chromatographymass spectrometry: Methods and preliminary results including toxicity studies with vibrofischeri. J. Chromatograph. A., 938: 187-197. DOI: 10.1016/S0021-9673(01)01154-2

15. Maron, C. and B.N. Ames, 1984. Revised Methods for the Salmonella Mutagenicity Test. In: Handbook of Mutagenicity Test Procedures, Kilbey, B.J., M. Legator, W. Nichols and C. Ramel (Ed.). Elsevier Science Publishers, Amsterdam, Oxford, New York, pp: 93-141.
16. Osaigboro, A.U. and C.R. Orhue, 2006. Influence of pharmaceutical effluent on some soil chemical properties and early growth of maize [Zea mays L]. Afr. J. Biotechnol. 5: 1612-1617. http://www.academicjournals.org/AJB/PDF/pdf200 6/18Sep/Osaigbovo\%20et\%20al.pdf

17. Pollution Prevention and Abatement Handbook of World Bank Group, 1998.

18. Velagati, R., P.K. Burns, M. Gill and J. Prothro, 2002. Impact of current good manufacturing practices and emission regulations and guidance on the discharge of pharmaceutical chemicals into the environment from manufacturing, use and disposal. Environ. Health Perspect., 110: 213-220. http://www.ehponline.org/members/2002/110p213220velagaleti/velagaleti-full.html

19. Tixier-Boichard, M., 2002. From phenotype to genotype: Major genes in chickens. World Poult. Sci. J., 58: 65-75. DOI: 10.1079/WPS20020008

20. US FDA Guidance for Industry, 1998. Oriental Assessment of Human Drugs and Biological Application CML 6, Revision 1. US Food and Drug Administration, Washington, DC.

21. Metcalfe, C. and B. Koenig, 2000. Drugs in sewage treatment plants in Canada. Proceeding of the Extended Abstract of the American Chemical Society National Meeting, San Francisco CA., USA., pp: 219.

23. Stan, H.J., T. Heberer and M. Linkerhägner, 1994. Occurrence of clofibric acid in the aquatic systemIs the use in human medical care the source of the contamination of surface ground and drinking water? Vom $\quad$ Wasser, 83: 57-57. http://direct.bl.uk/research/4C/37/EN022363529.ht $\mathrm{ml}$ ? source $=$ googlescholar 